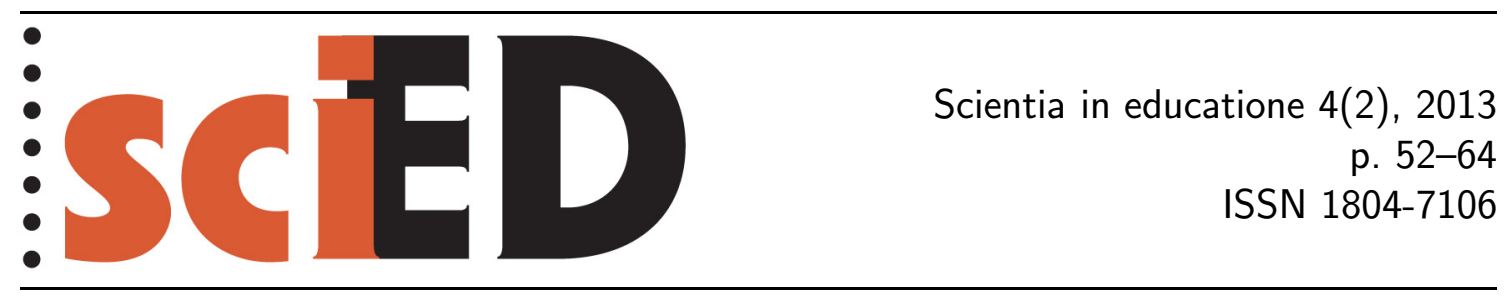

\title{
Experimenty s přírodními látkami v chemickém vzdělávání na SŠ - názory stř̌edoškolských učitelů
}

\author{
Michala Opatová, Simona Hybelbauerová
}

\begin{abstract}
Abstrakt
Tento článek přináší názory středoškolských učitelů chemie na téma experimenty s př́rodními látkami v chemickém vzdělávání. Prostřednictvím interaktivního dotazníku učitelé odpovídali na otázky $\mathrm{k}$ teoretické i experimentální výuce tohoto tématu. Cílem výzkumu bylo zjistit, jaké experimenty s přírodními látkami učitelé zařazují do výuky, jestli rozšiřují téma i do jiných oblastí, než jak je uváděno v rámcových vzdělávacích programech, a kde nacházejí ke zmíněným experimentům inspiraci. Výsledky výzkumu poslouží mj. ke zpracování sbírky s návody na inovované či méně známé experimenty s přírodními látkami.
\end{abstract}

Klíčová slova: přrírodní látky, střední škola, chemie, experimenty, dotazníkové šetření.

\section{The Experiments with Natural Compounds in Secondary School Chemistry Education - Opinions of Secondary School Teachers}

\begin{abstract}
The paper focuses on the opinions of secondary school chemistry teachers of 'Experiments with natural compounds in chemistry education'. The teachers answered the questions on the theoretical and experimental teaching of this topic in an interactive questionnaire. The main objective of our research was to investigate which experiments with natural compounds the teachers use in their classes, if teachers extend this topic to areas other than given in the curriculum document, the Framework Education Programme, and where teachers find the inspirations for their experiments. The results will be used, among others, to make a compilation of innovated or not well known experiments with natural compounds and instructions for these experiments.
\end{abstract}

Key words: natural compounds, secondary school chemistry, experiments, questionnaire survey. 


\section{1 ÚvOD}

V přehledu středoškolské chemie (Vacík, 1995) se popisují přírodní látky jako sloučeniny nebo jejich směsi vyskytující se v př́rodě. Patří sem jednoduché (př. kyselina mravenčí) i složité (př. nukleové kyseliny) sloučeniny. Podle výzkumu (Huvarová, 2010) je nejvíce používanou učebnicí chemie na středních školách (SŠ) Chemie pro čtyřletá gymnázia (Mareček, Honza, 2000), kde se mezi přírodní látky řadí živiny (lipidy, sacharidy, bílkoviny), biokatalyzátory (enzymy, vitaminy, hormony), nukleové kyseliny, steroidy, alkaloidy a terpeny. V porovnání s ostatními podtématy zde mají největší obsahový rozsah sacharidy, proteiny a lipidy. Ve zmíněné učebnici však nejsou zařazeny návody na experimenty. V jiných učebnicích chemie pro gymnázia (Banýr, 1995; Kolář, 1997; Eisner, Amann, 2000) se vyskytují experimenty zaměřené na př́rodní látky, jako je např. důkaz škrobu, redukujících sacharidů, biuretová reakce a denaturace bílkovin.

Téma přírodní látky se ve středoškolské chemii řadí tradičně až za učivo obecné, anorganické a organické chemie, promítá se ale i do učiva biochemie (RVP G, 2007). Bývá také díky výskytu látek v přírodním materiálu úzce spjato i s biologií. V současné době mají učitelé vzhledem k rámcovým vzdělávacím programům (RVP) možnost zvolit si rozsah vybraného tématu v celém ročním plánu chemie tak, aby stihli probrat vše, co je předepsané v jejich školním vzdělávacím programu (ŠSP), a zároveň aby mohli věnovat větší časový úsek vybranému tématu, např. přírodním látkám. Také si mohou vybrat, které experimenty zařadí do výuky, ke kterému tématu experimenty předvedou demonstračně, či které pokusy si žáci budou moci sami vyzkoušet při laboratorním cvičení.

Pro žáky na SŠ bývá chemie méně oblíbený předmět (Rusek, Pumpr, 2009). Co však žáky z chemie zaujme nejvíce, jsou právě experimenty (Rusek, 2011). Téma přírodní látky bývá žákům blízké, a to z důvodu přítomnosti látek ve známém materiálu, v rostlinách, potravinách, drogistickém zboží apod. Experimenty s přírodními látkami jsou pro žáky atraktivní právě tím, že si mohou výchozí materiál sami přinést $\mathrm{z}$ domova nebo přírody a např. izolovat prŕrodní látku, provést s ní jednoduché reakce, dokázat její př́tomnost ve směsi a další.

Hlavním cílem tohoto výzkumu bylo zjistit, jaká podtémata přírodních látek, kromě výše zmíněných stěžejních témat uvedených v RVP, učitelé vyučují, jaké experimenty s přírodními látkami učitelé provádějí nebo nechají své žáky realizovat při laboratorním cvičení, a kde získávají inspiraci k těmto experimentům.

\section{DříVE PROVEDENÉ VÝZKUMY ZAMĚŘENÉ MIMO JINÉ NA Př́́RODNÍ LÁTKY A EXPERIMENTY}

Ve výzkumu z roku 2006-2009 (Teplá, Klímová, 2011), který byl zaměřený na obsah učiva biochemie a ICT na SS̆, se některé otázky v dotazníkovém šetření týkaly i přírodních látek (nukleové kyseliny, bílkoviny, sacharidy, lipidy, enzymy a vitaminy). Dotazníkového šetření, kde cílovou skupinou byli učitelé chemie převážně z gymnázií, se zúčastnilo 104 SŠ. Výsledkem bylo zjištění, že přrírodní látky (uvedené výše) patří mezi často vyučovaná biochemická témata a že se řadí mezi méně obtížné učivo. K experimentům s přírodními látkami v tomto dotazníkovém šetření nedošlo.

Při dotazníkovém šetření z let 2007-2009 (Bőhmová, 2009), které bylo zaměřené na zařazování experimentů do výuky chemie, se zjistilo, že učitelé nejčastěji ukazují demonstrační pokusy, méně často mají žáci možnost sami provádět experimenty při laboratorním cvičení. 
Z výzkumu PISSA 2006 (Palečková, 2006), který se mimo jiné vztahoval k využití experimentů v př́rodovědné výuce, je zřejmé, že se v ČR velmi málo provádí praktické pokusy v laboratoři. Závěr z výzkumu TIMSS 2007 (Tomášek, 2007) ukazuje, že žáci v ČR při realizaci experimentů dosahují pouze průměrných výsledků v porovnání se zahraničím.

\section{VLASTNÍ PEDAGOGICKÝ VÝZKUM}

Výše uvedené výzkumy nebyly zaměřeny na experimenty s přírodními látkami a na doprovodné informace. Proto byl vytvořen dotazník, který měl za úkol zjistit odpovědi na předem zvolené otázky, jež se týkají výše uvedené problematiky, od náhodně vybraných středoškolských učitelů chemie v ČR. V tomto případě byl zvolen elektronický dotazník, a to z důvodů rychlého zpracování, finanční nenáročnosti a menší časové náročnosti pro učitele.

Dotazník je často volenou metodou pedagogického výzkumu (Gavora, 2000). Námi vytvořený dotazník obsahoval 9 otázek, u většiny byl výběr z několika předvolených odpovědí, jedna otázka obsahovala otevřenou odpověd' a jedna otázka obsahovala odpověd’ pouze ano/ne. Součástí dotazníku byla možnost vyjádřit svůj vlastní názor k problematice, ale i ke struktuře dotazníku. ${ }^{1}$

Otázky byly formulovány takto:

1. Jakou dotaci hodin má předmět chemie na Vaši škole (vy̌̌ši gymnázium)?

cíl: zjistit, zda na vybrané SŠ mají alespoň 2 hodiny chemie/týdně a kolik ročníků

2. Maji žáci rozvrhované laboratorní cvičení z chemie (mimo běžné hodiny chemie)?

cíl: získat informace o možnosti vlastní činnosti žáků při laboratorním cvičení, a kolikrát za pololetí

3. Chemické experimenty zařazuji:

cíl: ověřit si, zda učitel zařazuje experimenty jen demonstračně nebo v rámci laboratorního cvičení nebo vůbec

4. Podle čeho vybíráte experimenty do výuky?

cíl: zjistit, z čeho učitel čerpá inspiraci pro experimenty, zda z VŠ poznámek, učebnic, ...

5. Využiváte při experimentech běžný materiál, např. potraviny, nápoje, drogistické zboží?

cíl: dozvědět se, zda je tento běžný materiál součástí experimentů, či zda učitel nezná experimenty s ním

6. Ve kterém ročníku vyučujete téma přírodní látky?

cíl: zjistit, ve kterém ročníku je zařazeno téma přírodní látky

\footnotetext{
${ }^{1}$ Dotazník je dostupný na internetových stránkách https://docs.google.com/spreadsheet/ viewform?formkey=dEJVNUdEQURyRWlvUVJkV19vX016c2c6MQ.
} 
7. Přri experimentech s př́rodními látkami se zaměruji na:

cíl: ověřit si, které přírodní látky učitel vybírá pro experimenty

8. Uvedte, prosím, názvy experimentů s přírodními látkami, které zařazujete do výuky chemie:

cíl: uvést přesné názvy experimentů s přírodními látkami

9. Uvítali byste sbírku experimentio s př́rodními látkami a materiálem z domácnosti?

cíl: zjistit, zda je zájem o další návody na experimenty, a motivovat učitele k vyplnění dotazníku

\section{Postup VlastNíHo PEDAGOGICKÉHO VÝZKUMU}

Nejprve byly formulovány otázky a k nim byly vytvořeny možné odpovědi. U většiny otázek byla poslední odpovědí „jiná možnost“, kde učitel mohl odpovědět podle svého úsudku a rozepsat se více $\mathrm{k}$ dotazovanému tématu, nebo měl možnost vypsat více odpovědí do tohoto nabízeného políčka ( $\mathrm{z}$ důvodu, že v elektronickém dotazníku nešlo označit více odpovědí současně).

Poté byl vytvořen interaktivní dotazník pomocí služby Google Docs, která je bezplatná. Následně byli osloveni náhodně vybraní učitelé chemie na SS̆, převážně z gymnázií, kde se předmět chemie učí v širším rozsahu. Pokud bylo možné dohledat e-mail přímo na učitele chemie na vybrané škole, byl mu zaslán mail s prosbou o vyplnění dotazníku. Jinak byl dotazník zaslán e-mailem na sekretariát školy, s žádostí o předání učiteli chemie. Snahou bylo rozeslat dotazník do všech krajů v ČR. Odpovědi učitelů, kteří dotazník vyplnili, byly zpracovány v programu Microsoft Excel.

Žádosti o vyplnění dotazníku byly poslány během druhého pololetí školního roku 2011/2012 celkem na 102 SŠ v ČR.

\section{VÝSLEDKY DOTAZNÍKOVÉHO ŠETŘENÍ NA RŮZNÝCH TYPECH STŘEDNÍCH ŠKOL A V JEDNOTLIVÝCH KRAJÍCH}

Z celkem 102 SS̆ se vyplněný dotazník vrátil z 57, návratnost činí tedy $56 \%$ (viz tabulka 1). Na stejné škole bylo osloveno více učitelů, a to kvůli možnosti výběru jiných experimenti̊, než využívá kolega, čerpání inspirace pro experimenty a další. Dotazník vyplnilo celkem 68 učitelů z oslovených 132, což je $51 \%$.

Tab. 1: Porovnání gymnázií a SOŠ vzhledem k poslané žádosti o vyplnění dotazníku

\begin{tabular}{|l|c|c|c|}
\hline Typ Sธ̌ & Počet oslovených škol & $\begin{array}{c}\text { Počet škol, } \\
\text { kde byl vyplněn } \\
\text { dotazník }\end{array}$ & Návratnost \\
\hline Gymnázia & 93 & 52 & $56 \%$ \\
\hline SOŠ & 9 & 5 & $56 \%$ \\
\hline
\end{tabular}

Z tabulky 1 je zřejmé, že žádost o vyplnění dotazníku byla poslána především na gymnázia. Vyplněné dotazníky př̌̌šly z 52 gymnázií a z 5 středních odborných škol (SOŠ). 
Tab. 2: Poslané žádosti o vyplnění dotazníku na střední školy a jejich návratnost

\begin{tabular}{|c|c|c|c|}
\hline Kraj & 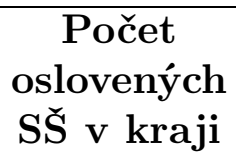 & $\begin{array}{l}\text { Počet SŠ v kraji, } \\
\text { kde byl } \\
\text { vyplněn dotazník }\end{array}$ & $\begin{array}{c}\text { Návratnost } \\
\text { dotazníku } \\
\text { v kraji }\end{array}$ \\
\hline Hlavní město Praha & 25 & 18 & $72 \%$ \\
\hline Středočeský kraj & 12 & 4 & $33 \%$ \\
\hline Ústecký kraj & 5 & 4 & $80 \%$ \\
\hline Plzeňský kraj & 4 & 4 & $100 \%$ \\
\hline Jihočeský kraj & $\overline{11}$ & 8 & $72 \%$ \\
\hline Kraj Vysočina & 5 & 4 & $80 \%$ \\
\hline Královéhradecký kraj & 7 & 1 & $14 \%$ \\
\hline Pardubický kraj & 3 & 0 & $0 \%$ \\
\hline Moravskoslezský kraj & 12 & 7 & $58 \%$ \\
\hline Olomoucký kraj & 5 & 3 & $60 \%$ \\
\hline Liberecký kraj & 2 & 2 & $100 \%$ \\
\hline Jihomoravský kraj & 10 & 1 & $10 \%$ \\
\hline Zlínský kraj & 1 & 1 & $100 \%$ \\
\hline
\end{tabular}

Z tabulky 2 vyplývá, že z každého kraje v ČR došel vyplněný dotazník alespoň z 1 SS̆, kromě kraje Pardubického, kam byly poslány žádosti na 3 různé SS̆.

Na obrázku 1 je patrné rozmístění SS̆, ze kterých přišly vyplněné dotazníky. Pouze mimo Pardubický kraj jsou označena města se SŠ v každém kraji.

\section{Předledová mapa ČR - krajů s vyznačenými obcemi} zapojenými do dotazníkového šetření
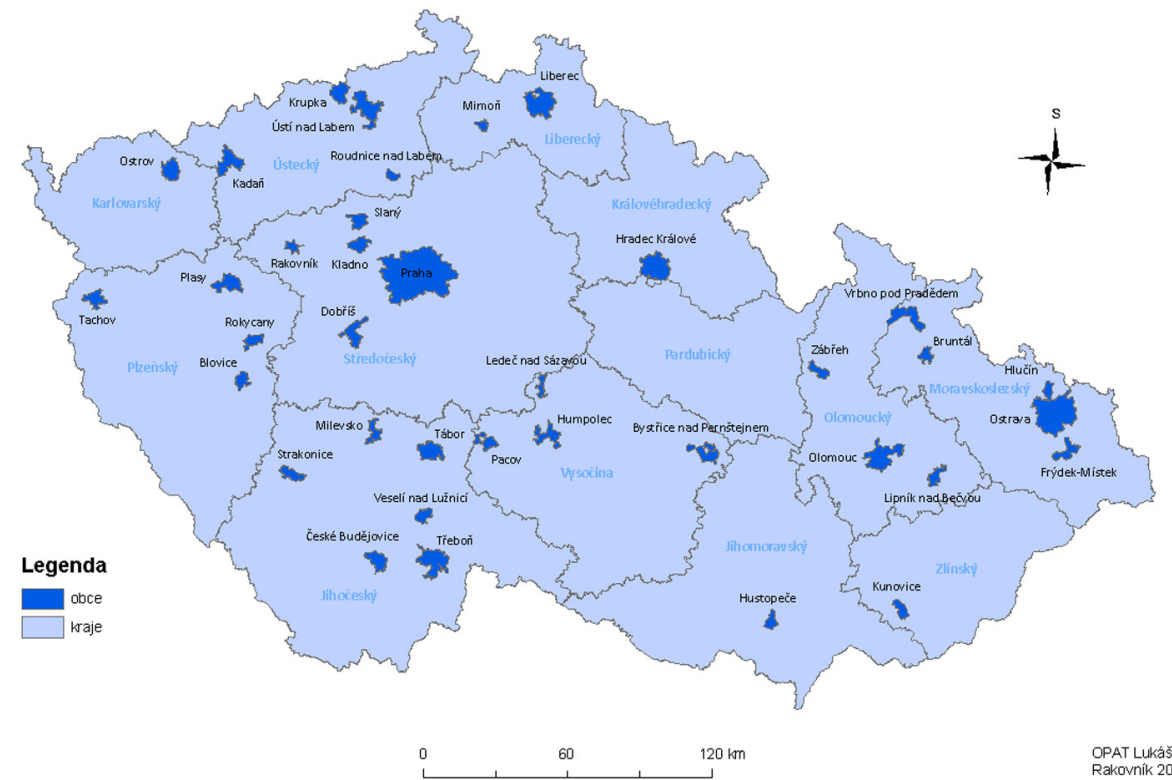

OPAT Lukášs

Obr. 1: Vyznačená města v krajích s vyplněnými dotazníky

\section{ODPOVĚDI STŘEDOŠKOLSKÝCH UČITELŮ NA OTÁZKY V DOTAZNÍKU}

V následujícím textu jsou uvedeny získané odpovědi od 68 středoškolských učitelů chemie, kteří vyplnili dotazník. Odpovědi jsou graficky zpracovány a okomentovány. Počet odpovědí je přepočítán na procenta z důvodu větší přehlednosti. 
1. Jakou dotaci hodin má předmět chemie na Vaši škole (vyšši gymnázium)?

a) 2 hodiny týdně (1.-4. ročník)

b) 2 hodiny týdně (1.-3. ročník)

c) jiná možnost

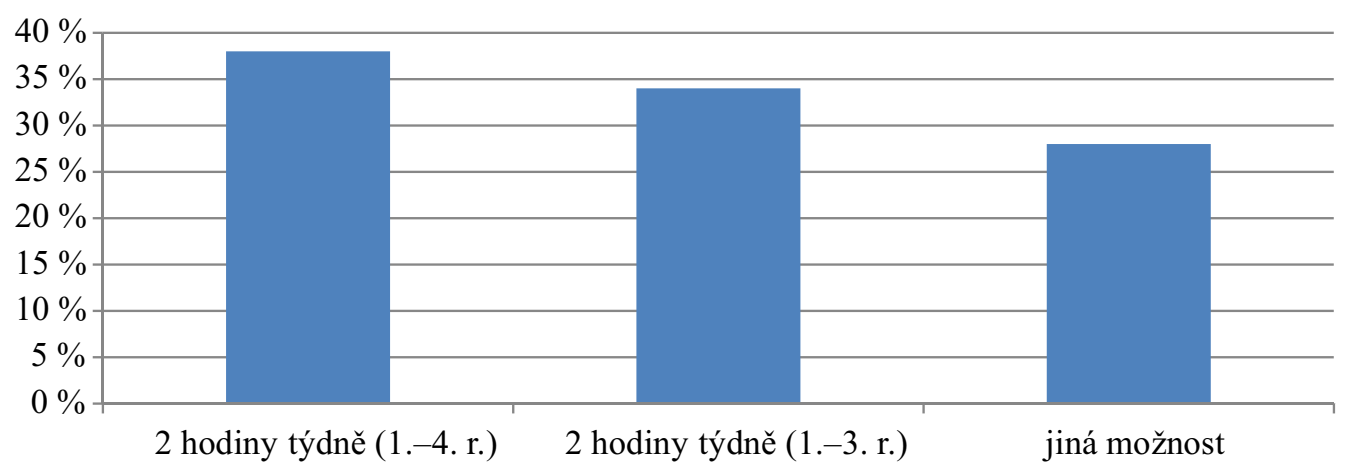

Obr. 2: Analýza odpovědí na 1. otázku

Z grafu na obr. 2 vyplývá, že nejvíce učitelů (38 \%) odpovědělo na 1. otázku variantou a), na jejich škole má předmět chemie dotaci 2 hodiny týdně (1. -4 . ročník). $34 \%$ odpovědí byla varianta b), a $28 \%$ učitelů odpovědělo za c) jinou možnost. Tato odpověd' byla velmi různorodá, učitelé se většinou neshodovali, pravděpodobně z důvodu různých typů škol (gymnázium - SOŠ). Jako odpovědi byly uváděny např. 2 hodiny (1.-2. ročník), 4 hodiny (1. ročník) a 2 hodiny (2. ročník), 3 hodiny (1.-3. ročník) atd.

2. Maji žáci rozvrhované laboratorní cvičení z chemie (mimo běžné hodiny chemie)?

a) ano, více než 3krát za pololetí

b) ano, maximálně 2krát za pololetí

c) ne, žáci maji laboratorni cvičení v rámci běžné hodiny chemie

d) ne, vưbec

e) jiná možnost

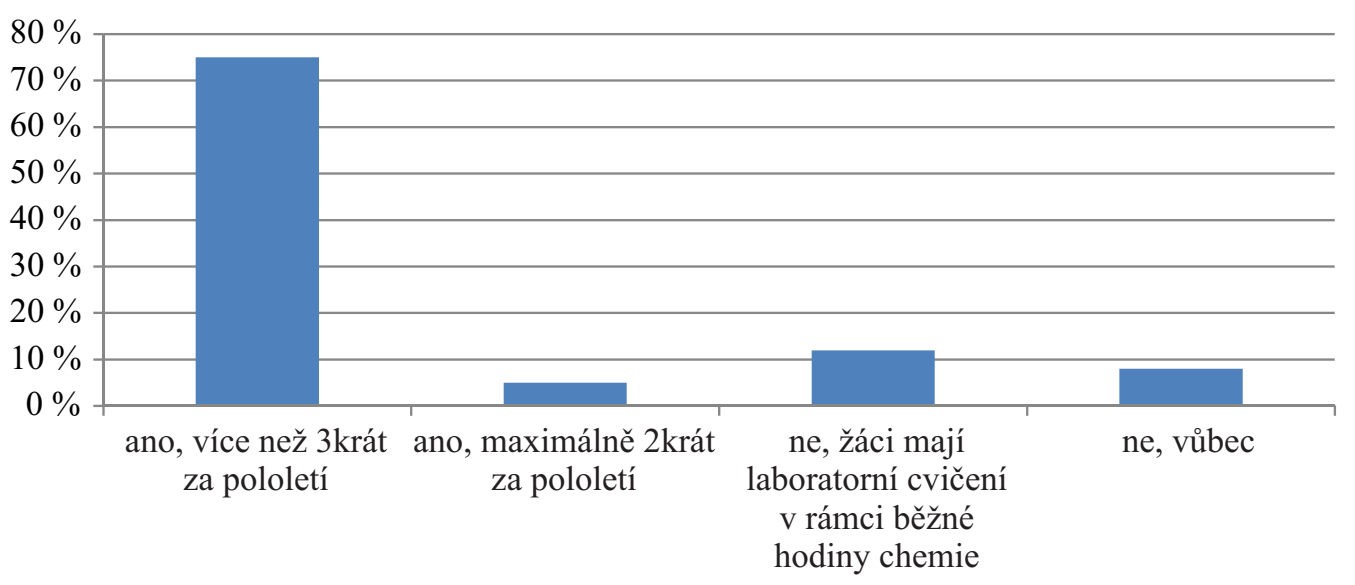

Obr. 3: Analýza odpovědí na 2. otázku

Z grafu na obr. 3 je zřejmé, že učitelé na druhou otázku odpovídali především pomocí možnosti za a) ano, více než 3krát za pololetí (75\%). Mnozí zaškrtli variantu za e) jiná možnost, kde uvedli, že žáci mají laboratorní cvičení např. jen ve 2. ročníku nebo ve 2. a 3. ročníku nebo jako samostatný předmět. Tyto odpovědi jsou teoreticky odpovědí za a), proto jsou sem přeřazeny. $8 \%$ 
odpovědí, překvapivě ze třech gymnázií, bylo pro variantu za d) ne, vůbec. Což znamená, že žáci na těchto školách pravděpodobně nemají možnost vyzkoušet si sami experimentální činnost v rámci výuky chemie. Varianta za e) není zařazena do grafu, neboť všechny odpovědi učitelů v této variantě spadají do varianty a).

3. Chemické experimenty zařazuji:

a) v rámci laboratorního cvičení

b) při demonstracích ve výuce

c) $v$ maturitním seminári

d) nezařazuji

e) jiná možnost

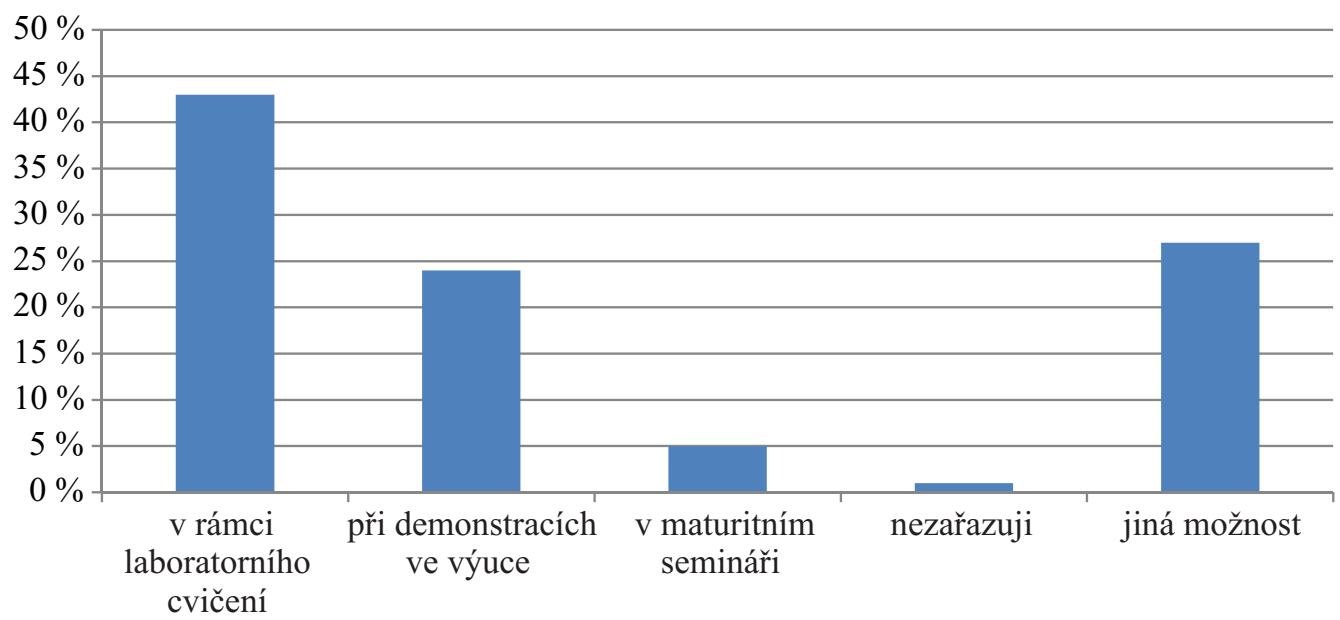

Obr. 4: Analýza odpovědí na 3. otázku

Z grafu na obr. 4 je patrné, že učitelé zapojení do dotazníkového šetření nejvíce zařazují experimenty v rámci laboratorního cvičení (43\%). Variantu za e) si vybrali učitelé, kteří uvedli více možností, např. že zařazují experimenty do laboratorního cvičení i při demonstracích (7krát uvedeno) nebo do laboratorního cvičení, demonstrací i semináře (2krát uvedeno). Pouze jeden učitel uvedl, že nezařazuje experimenty.

4. Podle čeho vybíráte experimenty do výuky?
a) z učebnic
b) z vysokoškolských poznámek
c) z médii, časopisů,...
d) jiná možnost

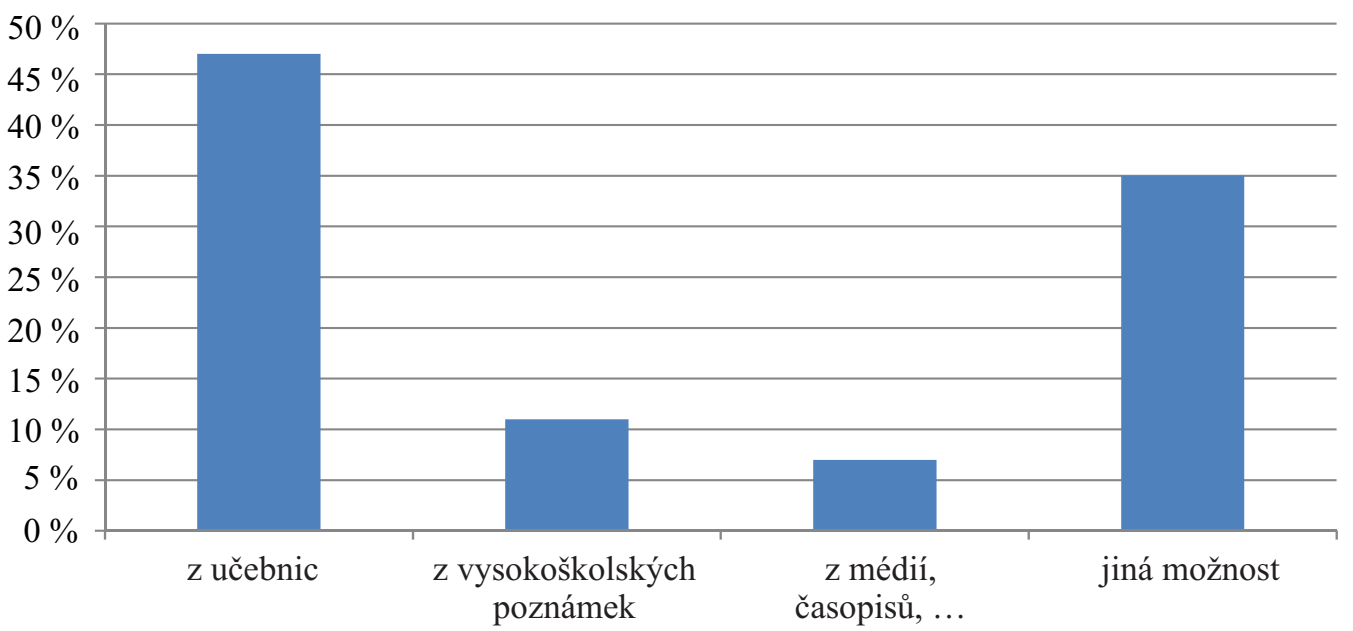

Obr. 5: Analýza odpovědí na 4. otázku 
Z grafu na obr. 5 vyplývá, že většina dotazovaných učitelů $(47 \%)$ vybírá experimenty pouze z učebnic, variantu za d) — jinou možnost - si vybralo $35 \%$ učitelů. Ti uvedli, že využívají všechny uvedené možnosti, nebo mají vlastní návody, nebo čerpají z vlastní zkušenosti z dřívější praxe v laboratoři. Jeden učitel uvedl, že čerpá inspiraci z akcí např. na PřF UK v Praze nebo VŠCHT Praha. Ti, co uvedli variantu za c), dodali, že čerpají i z internetu.

5. Využíáte při experimentech běžný materiál, např. potraviny, nápoje, drogistické zbožı?

a) ano

b) ne, protože provádím jiné experimenty

c) ne, protože neznám tyto experimenty

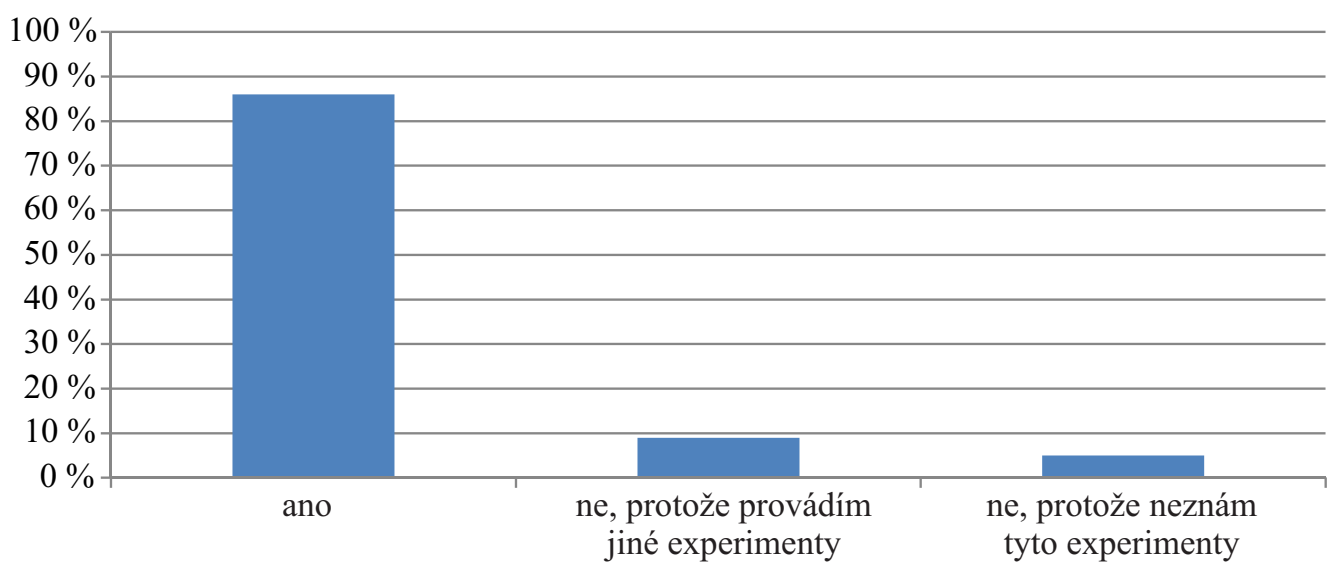

Obr. 6: Analýza odpovědí na 5. otázku

Z grafu na obr. 6 lze vyčíst, že většina učitelů ( $86 \%$ ) využívá uvedený běžný materiál při experimentech. Pouze $5 \%$ dotazovaných učitelů uvedlo, že nezná experimenty s tímto materiálem.

6. Ve kterém ročníku vyučujete téma př́rodní látky?

a) ve třetím

b) ve čtvrtém

c) jiná možnost

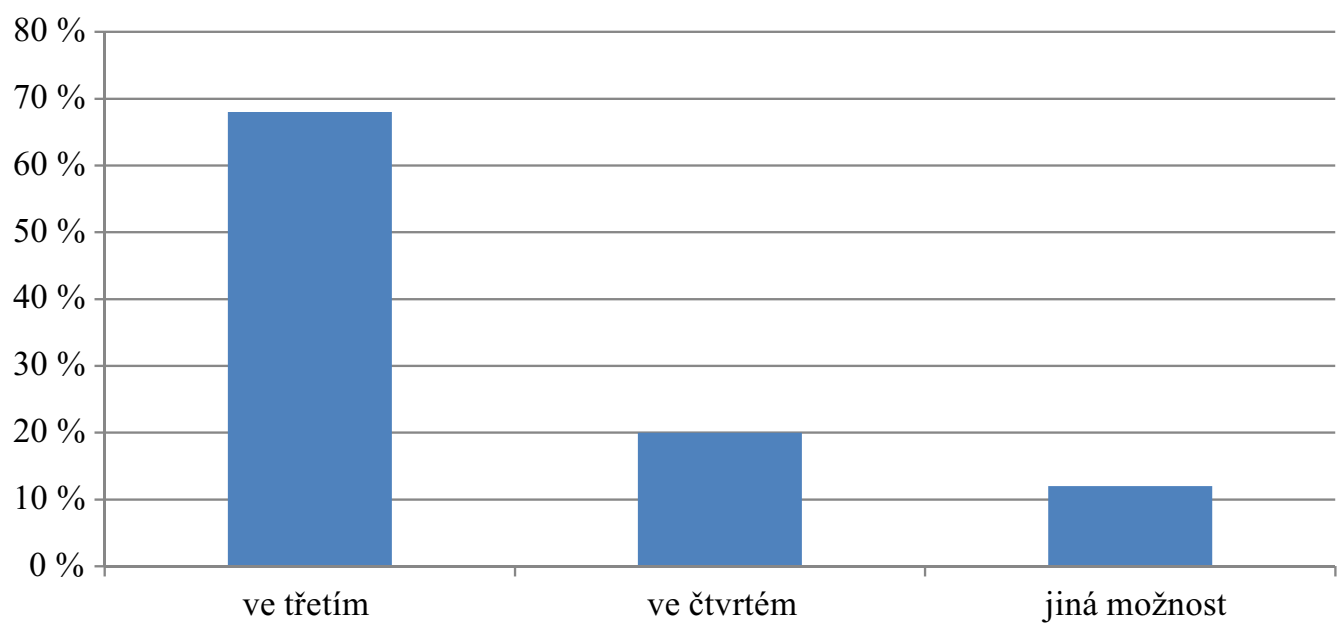

Obr. 7: Analýza odpovědí na 6. otázku

Z grafu na obr. 7 je zřejmé, že nejčastěji (68 \%) byla učiteli zvolena možnost za a), téma př́rodní látky vyučují ve třetím ročníku. $12 \%$ učitelů uvedlo 
odpověd’ za c) s odůvodněním, že vyučují toto téma např. ve druhém ročníku nebo ve třetím i čtvrtém ročníku nebo jen v semináři.

7. Při experimentech s př́rodními látkami se zaměřuji na:

a) sacharidy

b) proteiny

c) lipidy

d) nukleové kyseliny

e) barviva

f) vưně

g) vitaminy

h) jiná možnost

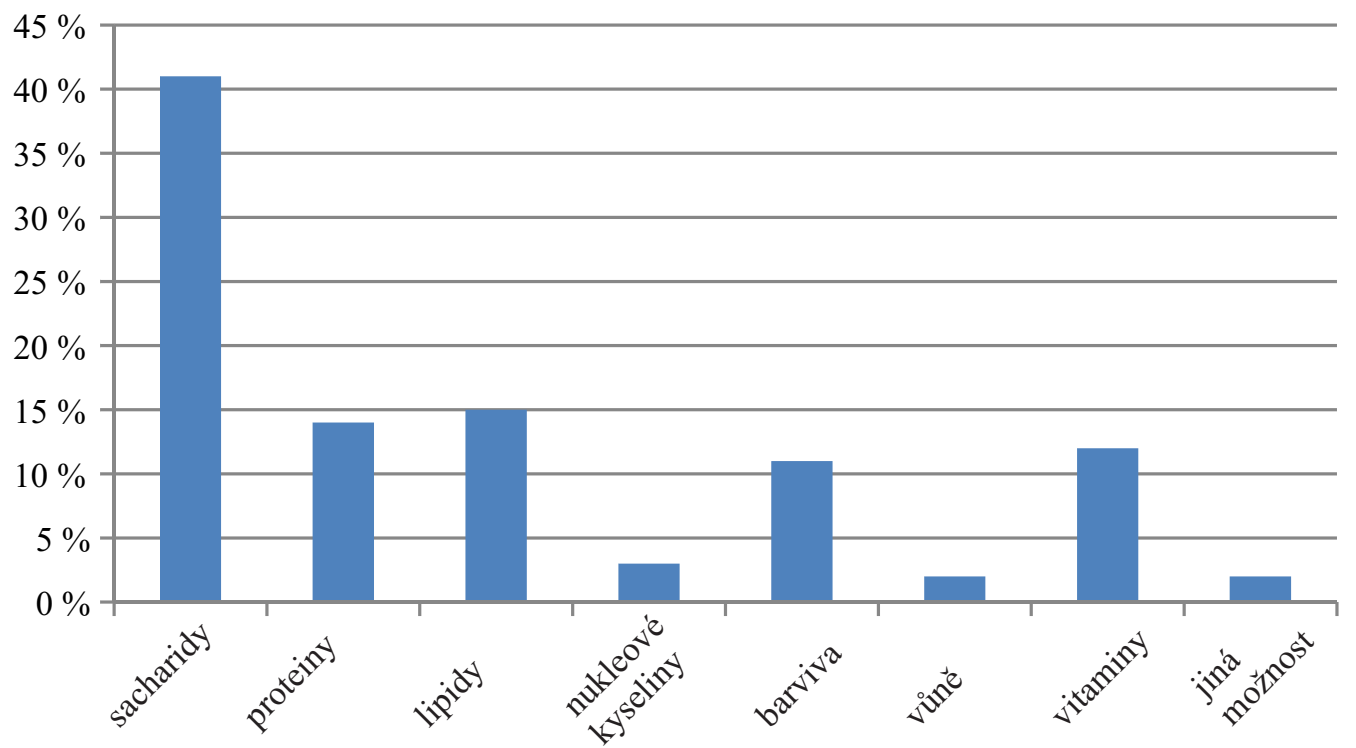

Obr. 8: Analýza odpovědí na 7. otázku

Z grafu na obr. 8 je patrné, že učitelé se nejvíce zaměřují při svých experimentech s prŕrodními látkami na sacharidy (41 \%), nejméně se pak věnují nukleovým kyselinám (3\%), vưním (2\%) či jiným tématům (učitelé zde uváděli např. terpeny, alkaloidy, glykosidy).

8. Uvedte, prosím, názvy experimenti̊ s přírodními látkami, které zařazujete do výuky chemie:

Tato otevřená otázka je pro celé dotazníkové šetření nejpřínosnější, protože odpověd’ poskytuje informace, jaké experimenty s př́rodními látkami učitelé zařazují do výuky. $\mathrm{Z}$ odpovědí lze vytvořit podle podtémat jednotlivé kategorie (uvedené názvy experimentů jsou autentické odpovědi od učitelů):

Experimenty se sacharidy:

- Důkaz sacharidů - 45krát zmíněno

- Hydrolýza škrobu - 7krát zmíněno

- Faraonovi hadi - 5krát zmíněno

- Hoření cukru se skořicí, modrá baňka, výroba papíru - jednou zmíněno 
Experimenty s bílkovinami:

- Důkaz bílkovin (biuretová reakce) - 30krát zmíněno

- Denaturace bílkovin - 11krát zmíněno

- Xanthoproteinový test - 6krát zmíněno

- Experimenty s mlékem - 2krát zmíněno

- Výroba tvarohu - jednou zmíněno

Experimenty s lipidy:

- Výroba a vlastnosti mýdla - 15krát zmíněno

- Důkaz lipidů - 6krát zmíněno

- Rozpustnost lipidů - 3krát zmíněno

- Cholesterol v tucích - 2krát zmíněno

- Teplota měknutí tuků, olejová lampa, dělení oleje s vodou, rozlišení rostlinného a minerálního oleje - jednou zmíněno

Experimenty s barvivy:

- Anthokyaniny (př. z červeného zelí, indikátor pH) - 12krát zmíněno

- Chromatografie - 11krát zmíněno

- Extrakce barviva (př. chlorofylu a následná fluorescence) - 5krát zmíněno

- Odbarvení s aktivním uhlím, duha z rajčatové štávy, reakce barviv, barvení látek - jednou zmíněno

Experimenty s vitaminy:

- Důkaz vitaminů (především vitaminu C) - 14krát zmíněno

- Vlastnosti vitaminů (např. rozpustnost) - 2krát zmíněno

Ostatní experimenty s př́rodními látkami:

- Enzymy - př. trávení potravin, funkce ptyalinu - 12krát zmíněno

- Destilace rostlinných silic s vodní párou - 8krát zmíněno

- Experimenty s alkaloidy (př. izolace kofeinu) - 6krát zmíněno

- Př́iprava vůně (esteru) - 5krát zmíněno

- Experimenty s octem - 3krát zmíněno

- Po stopách kuřáka - 3krát zmíněno

- Důkaz prvků v přírodních látkách - 3krát zmíněno

- Konec gumového medvídka - 2krát zmíněno

- Ostatní jednou zmíněné: izolace hesperidinu z pomerančové kůry, dusičnany v ovoci a zelenině, stanovení aditiv v potravinách, rozbor piva, složení kostí, kyselina štavelová ve štovíku 
9. Uvítali byste sbírku experimenti̊ s př́rodními látkami a materiálem z domácnosti?

a) ano

b) $n e$

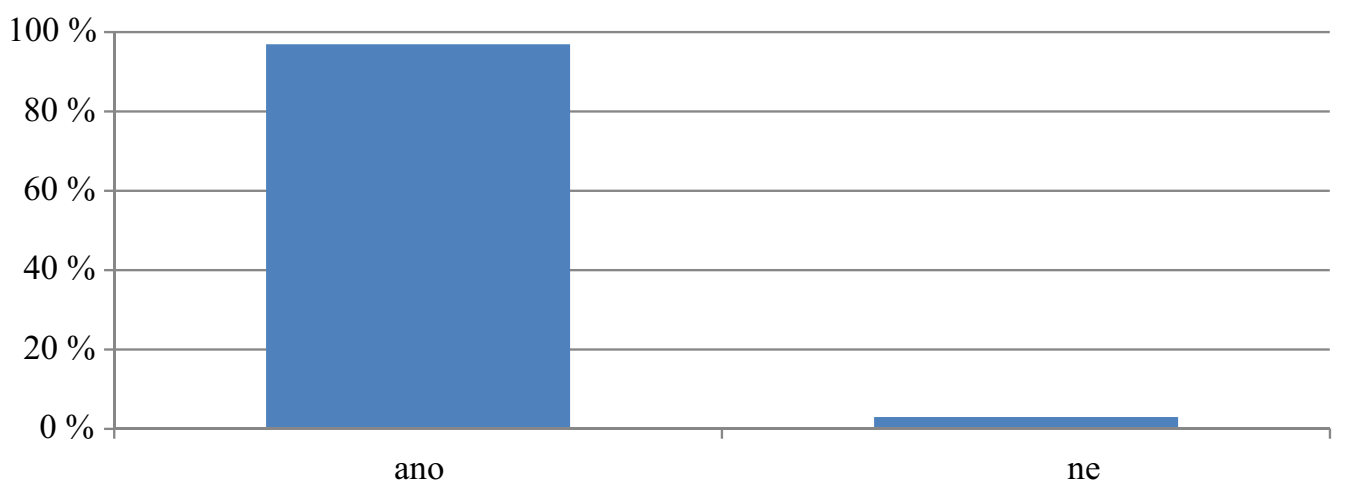

Obr. 9: Analýza odpovědí na 9. otázku

Z grafu na obr. 9 vyplývá, že učitelé zapojeni do tohoto výzkumu by téměř všichni měli zájem o výše zmiňovanou sbírku experimentů.

\section{DiskuZE}

Z oslovených 102 SŠ (93 gymnázií a 9 SOŠ) se do tohoto dotazníkového šetření zapojilo 57 SS̆ (68 učitelů chemie). Šlo pouze o výzkum orientační se snahou zjistit informace $\mathrm{k}$ dané problematice ze všech krajů u náhodně vybraných středních škol v ČR. Byly osloveny především fakultní školy PřF UK a všem zúčastněným byla nabídnuta připravovaná sbírka experimentů, což pravděpodobně přispělo k poměrně vysoké návratnosti vyplněných dotazníků. U škol Pardubického kraje však nedošlo ke spolupráci. Výzkum byl realizován na SŠ gymnaziálního typu, protože se zde chemie vyučuje vyšší počet hodin než na jiných SS̆, a na SOŠ s chemickým zaměřením. Učitelé odpovídali v rámci interaktivního dotazníku, někteří podrobně vyjadřovali své názory, jiní napsali, že by to byla obsáhlá odpověd', tak uvedli jen část. Tím mohlo dojít ke zkreslení výsledků. Ale i přesto se z výzkumu zjistily zajímavé informace o výuce př́rodních látek na SS̆ o a experimentech s nimi, které by se daly shrnout takto:

Na SŠ, které se zúčastnily dotazníkového šetření, se vyučuje chemie s dotací minimálně 2 hodiny týdně v 1 . a 2 . ročníku. Nejčastěji se vyučuje 2 hodiny (1.-4. ročník). $\mathrm{Na}$ většině oslovených škol mají žáci možnost vyzkoušet si experimenty v rámci laboratorního cvičení. Experimenty jsou často zařazovány do výuky demonstračně, při laboratorním cvičení a v semináři. Učitelé si vybírají experimenty především z tištěných materiálů (učebnice, vysokoškolské poznámky, časopisy atd.). Většina učitelů zná experimenty s běžným materiálem, jako jsou potraviny, nápoje, drogistické zboží atd. Téma přírodní látky se nejčastěji vyučuje ve třetím ročníku. U dotazovaných učitelů jsou nejvíce zařazovanými experimenty s př́rodními látkami ty, které jsou zaměřené na sacharidy. Konkrétně byly zmiňovány důkazové reakce, hydrolýza škrobu, hoření sacharidů a modrá baňka. Z dalších do výuky zařazovaných experimentů byly zmíněny experimenty s bílkovinami, a to do̊kaz bílkovin (biuretová reakce), experimenty s lipidy, u nichž převažoval experiment týkající se výroby a vlastností mýdla. Poměrně často byly uváděny experimenty s vitaminy, s anthokyaniny, a experimenty 
zaměřené na enzymy (ptyalin). Zajímavé byly i méně tradiční experimenty, jako např. izolace hesperidinu z pomerančové kůry, rozbor piva atd.

Jednoznačně z dotazníkového šetření vyplynulo, že učitelé mají zájem o další návody na experimenty s př́rodními látkami.

Je zřejmé, že téma přírodní látky poskytuje širokou působnost pro učitele ve výběru experimentů, at již tradičních či méně známých. Tím, že si žáci mohou přinést přírodní materiál sami z domova nebo z přírody, propojí si chemii s běžným životem a lépe si uvědomí důležitost tohoto předmětu. Na základě zájmu o další návody na experimenty s př́rodními látkami bude učitelům zapojeným do výzkumu zaslána sbírka, která přinese, doufejme, další inspiraci pro výuku chemie. Ohodnocení této sbírky učiteli může být dalším stupněm pro vytváření nových experimentů či jejich vylepšování.

\section{ZÁvĚR}

Dotazníkové šetření zaměřené na přírodní látky a experimenty s nimi přineslo jak předem předpokládané výsledky (např. ve kterém ročníku se vyučuje téma přírodní látky), tak i zajímavé odpovědi v podobě vypsaných experimentů s přírodními látkami. Na oslovených školách se tradičně učitelé nejčastěji zaměřují na experimenty se sacharidy, méně často na experimenty s okrajově probíranými látkami, jako jsou alkaloidy, terpeny, vůně a další.

Podle očekávání učitelé rádi uvítají další návody na experimenty s přrírodními látkami. Ty jim budou posílány v průběhu roku 2013. Naštěstí se nepotvrdila hypotéza, že na většině škol není dostatek času na laboratorní cvičení, a tudíž si žáci sami vyzkouší experimenty, které jsou nedílnou součástí výuky chemie.

Experimentům s př́rodními látkami bude jistě i nadále věnována pozornost, protože je to oblast, již lze stále prozkoumávat a pro niž je možné připravovat zajímavé experimenty s běžně dostupným materiálem či pomůckami.

\section{LITERATURA}

BANÝR, J., a kol. Chemie pro středni školy. Praha : SPN, 1995.

BÖHMOVÁ, H. Vzdělávání žáků v chemii prostřednictvím, jednoduchých experimentů s př́rodními látkami: podpora empirických poznávacích postupư a rozvoj souvisejicích kompetencí. Disertační práce. Praha : UK v Praze, 2009.

EISNER, W., AMANN, W., a kol. Chemie pro střední školy. Scientia, 2000.

GAVORA, P. Úvod do pedagogického výzkumu. Brno : Paido, 2000.

HUVAROVÁ, M. Nejpoužívanější středoškolské učebnice chemie na gymnáziích. Bakalářská práce. Olomouc : UP, 2010.

KOLÁ̊̌, K., a kol. Chemie organická a biochemie pro gymnázia. Praha : SPN, 1997.

MAREČEK, A., HONZA, J. Chemie pro čtyřletá gymnázia. 3. díl. Olomouc : 2000.

PALEČKOVÁ, J., a kol. Hlavní zjištění výsledků PISA 2006. Poradí si žáci s přírodnimi vědami? Praha : Ústav pro informace ve vzdělávání, 2007. 
Rámcový vzdělávací program pro gymnázia. [online]. Praha : VÚP, 2007. [cit. 2012-10-01]. Dostupné z:

〈http://vuppraha.cz/wp-content/uploads/2009/12/RVPG-2007-07_final.pdf

RUSEK, M. Postoj žáků k předmětu chemie na středních odborných školách. Scientia in educatione, 2011, 2(2), s. 39-58.

RUSEK, M., PUMPR, V. Výuka chemie na SOŠ nechemického směru. In Výzkum, teorie a praxe $v$ didaktice chemie XIX. Hradec Králové : Gaudeamus, 2009.

TEPLÁ, M., KLÍMOVÁ, H. Obsah učiva biochemie a použivání počítačové technologie na středních školách v ČR - výsledky dotazníkového šetření. In Media $4 U$ Magazine X3/2011. [cit. 2012-10-01].

Dostupné z: 〈http://www.media4u.cz/mmx32011.pdf〉

TOMÁŠEK, V., a kol. Výzkum TIMSS 200\%. Obstoji čeští žáci v mezinárodní konkurenci? Praha : Ústav pro informace ve vzdělávání, 2008.

VACÍK, J. Přehled středoškolské chemie. Praha : SPN, 1995.

\section{PODĚKOVÁNí}

Děkujeme všem středním školám zapojeným do výzkumu, hlavně učitelům chemie, za vyplnění dotazníku. Přejeme jim spoustu krásných experimentů, a to nejen s přírodními látkami. Mgr. Lukáši Opatovi patří poděkování za vytvoření mapy. V neposlední řadě děkujeme za finanční podporu projektu PRVOUK P42, a stejně tak děkujeme výzkumnému záměru MSM002162085.

Mgr. Michala Opatová - E-mail: opatova.michala@gmail.com RNDr. Simona Hybelbauerová, Ph.D. - E-mail: simona.hybelbauerova@gmail.com Univerzita Karlova v Praze, Př́rodovědecká fakulta katedra učitelství a didaktiky chemie Albertov 3, 12843 Praha 2, Česká republika 